A THEORY OF JUSTICE 



\title{
A THEORY OF JUSTICE
}

\author{
ORIGINAL EDITION
}

\section{JOHN RAWLS}

THE BELKNAP PRESS OF HARVARD UNIVERSITY PRESS

CAMBRIDGE, MASSACHUSETTS

LONDON, ENGLAND 


\section{For Mard}

(C) Copyright 1971 by the President and Fellows of Harvard College

All rights reserved

Printed in the United States of America

\section{Library of Congress Cataloging-in-Publication Data}

Rawls, John, 1921-

A theory of justice / John Rawls.

p. $\mathrm{cm}$.

Reprint. Originally published: 1971.

Includes bibliographical references and index.

ISBN 0-674-01772-2 (pbk. : alk. paper)

1. Justice. I. Title.

JC578.R38 2005

$320^{\prime} .01^{\prime} 1-\mathrm{dc} 22 \quad 2004060697$ 